\title{
GEOELECTRICAL SIGNATURES AND THEIR RELATIONSHIPS WITH THE LATERITIC HORIZONS: A CASE STUDY OF THE N4EN MINE'S IRON CAVE, CARAJÁS COMPLEX, BRAZIL
}

\author{
Guilherme A. S. Prosdocimi ${ }^{1}$, Marco Antonio S. Braga², \\ Marcelo R. Barbosa ${ }^{3}$ and luri Viana Brandi4
}

\begin{abstract}
The Brazilian speleological heritage is protected by laws, and every region where caves are present requires scientific studies to assist in environmental licensing. In the context of mining in iron formations, the near-surface geophysical studies using electroresistivity survey were performed in the cave N4E-0022, located at the N4EN iron mine, Carajás Complex, northern Brazil. The near-surface geophysical surveys generated continuous images that enhanced the lithostructural mapping of the lateritic profile, especially in places to which access by conventional methods was difficult. The electrical resistivity profiles were acquired with the Dipole-Dipole arrangement in the upper portion of the cave. Three sections were performed in SW-NE direction and two in SE-NW direction, totaling 435 meters of acquisition. The geoelectrical signatures were correlated with the lithologic logs of drillholes, the geophysical well logging and with the typical lateritic profile in the cave N4E-0022 surroundings. The results showed a satisfactory interpretation for the near-surface geoelectrical profiles and evolved to a comparison with the lateritic profile (lateritic crust, transition horizon, and saprolite horizon), providing inherent resistivity signatures for each modeled material.
\end{abstract}

Keywords: applied geophysics, iron cave, Carajás.

RESUMO. 0 patrimônio espeleológico brasileiro é protegido por leis, e qualquer região com a presença de cavidades precisa de estudos científicos para auxiliar 0 licenciamento de empreendimentos. No contexto da mineração em terrenos ferríferos, estudos geofísicos rasos utilizando eletrorresistividade foram executados na cavidade N4E-0022, localizada no extremo norte da Mina de N4EN, Complexo Carajás. A geofísica rasa gerou imagens contínuas que potencializaram o mapeamento litoestrutural do substrato rochoso, principalmente em locais de difícil acesso aos métodos convencionais. Os perfis de eletrorresistividade foram adquiridos com arranjo Dipolo-Dipolo na porção superior da cavidade. de modo paralelo entre si na porção superior da cavidade. Três seções foram executadas na direção SW-NE e duas na direção SE-NW, totalizando 435 metros de aquisição. As assinaturas geoelétricas das seções foram correlacionadas com as descrições litológicas de furos de sondagem, as perfilagens geofísicas de furos de sonda e o mapeamento de detalhe do perfil laterítico no entorno da cavidade N4E-0022, evidenciando um resultado satisfatório para as interpretações realizadas. Os resultados evoluíram para uma comparação com o perfil de alteração típico de rochas ferruginosas (crosta laterítica, horizonte de transição e saprolito), e forneceram assinaturas de resistividades inerentes a cada material modelado.

Palavras-chave: geofísica aplicada, caverna ferrífera, Carajás.

\footnotetext{
Corresponding author: Guilherme A. S. Prosdocimi

${ }^{1}$ Universidade Federal de Ouro Preto, Núcleo de Geotecnia da Escola de Minas (NUGE0), Ouro Preto, MG, Brazil 35400-000 - E-mails: guilhermepros@gmail.com gprosdocimi@ngg.com.br

2Universidade Federal do Rio de Janeiro, Centro de Pesquisa em Geofísica Aplicada (CPGA), Cidade Universitária, Illha do Fundão, Rio de Janeiro, RJ, Brazil 21941 -916 -E-mail:marcobraga@geologia.ufrj.br

${ }^{3}$ Vale S.A. - Licenciamento Ambiental e Espeleologia, Planejamento e Desenvolvimento de Ferrosos, Parauapebas, PA, Brazil 68516-000 - E-mail: marcelo.roberto.barbosa@vale.com

${ }^{4}$ Vale S.A. - Licenciamento Ambiental e Espeleologia, Planejamento e Desenvolvimento de Ferrosos, Nova Lima, MG, Brazil 34000-000 -E-mail: iuri.brandi@vale.com
} 


\section{INTRODUCTION}

Since the 1970s, when iron deposits and their speleological heritage were discovered, the region of Carajás, Pará State, has gained prominence in the research on genesis of natural caves in ferruginous rocks environments. Natural caves need technical and legal subsidies to ensure their structural stability, patrimonial and physical security, mainly because of the evolution and modification in their space.

In the context of intense technical and legal development, there has been an increasing demand for multidisciplinary studies related to rock mechanics, hydrogeology, seismology, numerical modeling, geophysics, risk analysis, etc., in order to comply with granted speleological restrictions. Most of these restrictions were formally established by federal laws and based on the analysis of speleometric, archaeological, cultural and biological attributes. The cave was deemed relevant due to its specific attributes, which generated different levels of protection. For the industry, the challenge was to develop, through such studies, methodologies that would ensure the physical integrity of the cavity during its operations and, consequently, claim the use of previously impeded areas.

The study of natural caves in ferriferous terrains is a growing field of research in the Brazilian speleological context. Until the beginning of the last century, most of the speleological studies widely disseminated in Brazil referred exclusively to the carbonate rock caves, such as limestones and dolomites. The number of registered cave units in iron formations showed a significant increase between 2005 and 2014 in the states of Minas Gerais and Pará, Brazil, as a result of studies related to environmental licensing.

The use of near-surface geophysics, such as electroresistivity survey, is extensively recognized in the speleological literature, however, most geophysical works are restricted to acquisitions in karst features related to carbonate rocks (e.g. Morgan et al., 1999; Francsik \& Nyari, 1999; Pellerin, 2002; Manney et al., 2005). Geophysical studies in iron caves are still incipient in the scientific context. As an example of applicability, Cardoso (2016) used shallow geophysical methods (electrical resistivity, magnetometry and radiometry) as a tool in the prospecting of caves in the Quadrilátero Ferrífero region. Barbosa et al. (2016a, 2016b), Barbosa et al. (2017), Prosdocimi et al. (2018) and Gama et al. (2018) demonstrated important lithostructural aspects of iron caves through the integration of geophysical methods. Recently, Barbosa (2018) developed an electrical resistivity methodology for assessing iron cave stability.

\section{N4E-0022 CAVE AND AREA CHARACTERIZATION}

The study area is in the N4EN iron mine, where the selected cave N4E-0022 is located. This mine is part of the Vale S. A. mining complex in Serra Norte, Carajás, southeast of the state of Pará, Brazil (Fig. 1).

The iron caves of the Carajás-PA region are located in high altitudes ranging from 600 to 700 meters above sea level. According to Piló \& Auler (2009), they usually develop on the edges of slopes, headwaters and drainages. The selected cave N4E-0022 is in a 9 meters high slope (Fig. 2).

The cave has 3 main spans (Fig. 3): in the north span there are registers of water puddles on the low permeability floor; in the east span there are ferriferous fractured blocks, mainly on the ceiling and walls. The main span stretches along the NW-SE direction and narrow conduits connect the spans. The ceilings and walls of the cave are irregular and there are records of drips, and the floor shows conditions of an outward drainage pattern (Carste, 2013).

A geostructural mapping shows that this cave is in the contact between two lithotypes: ferruginous lateritic crust and lateritic iron formation. The ferriferous rocks are very fragmented, with weathered sectors. Structurally, they exhibit a compositional banding with NS and NNW main directions; the fractures are very penetrative and open, which indicates predominance of NW/subvertical direction (Carste, 2013).

Cavity N4E-0022 is an example of a cave that evolved through independent spans and subsequent connections (Carste, 2013). The largest spans are at higher topographic levels and the weathering process allows a faster expansion of its galleries. As ferruginous cavities commonly do, cave N4E-0022 presents genesis in the superficial portions of the laterization profile through the combined action of chemical processes (formation of ferrous and aluminum complexes and removal of unstable clay minerals with $\mathrm{Fe}, \mathrm{Al}$ and $\mathrm{Si}$ content) and subsequent erosive action of physical processes (Pinheiro \& Maurity, 1988). The increasing of porosity and permeability in ferruginous environments, along with the removal of a thin layer of gibbisite particles, triggers the appearance of increasingly abundant voids, and thus the formation of cavities. These cavities are mainly located at the irregular interface between the lateritic crust and saprolite zone, indicating low density zones. Given the small size of the caves in Carajás region, the morphological pattern is inhibited. They feature narrow entrances and conduits, small spans and an average horizontal projection of 33 meters, approximately (Piló \& Auler, 2009). 


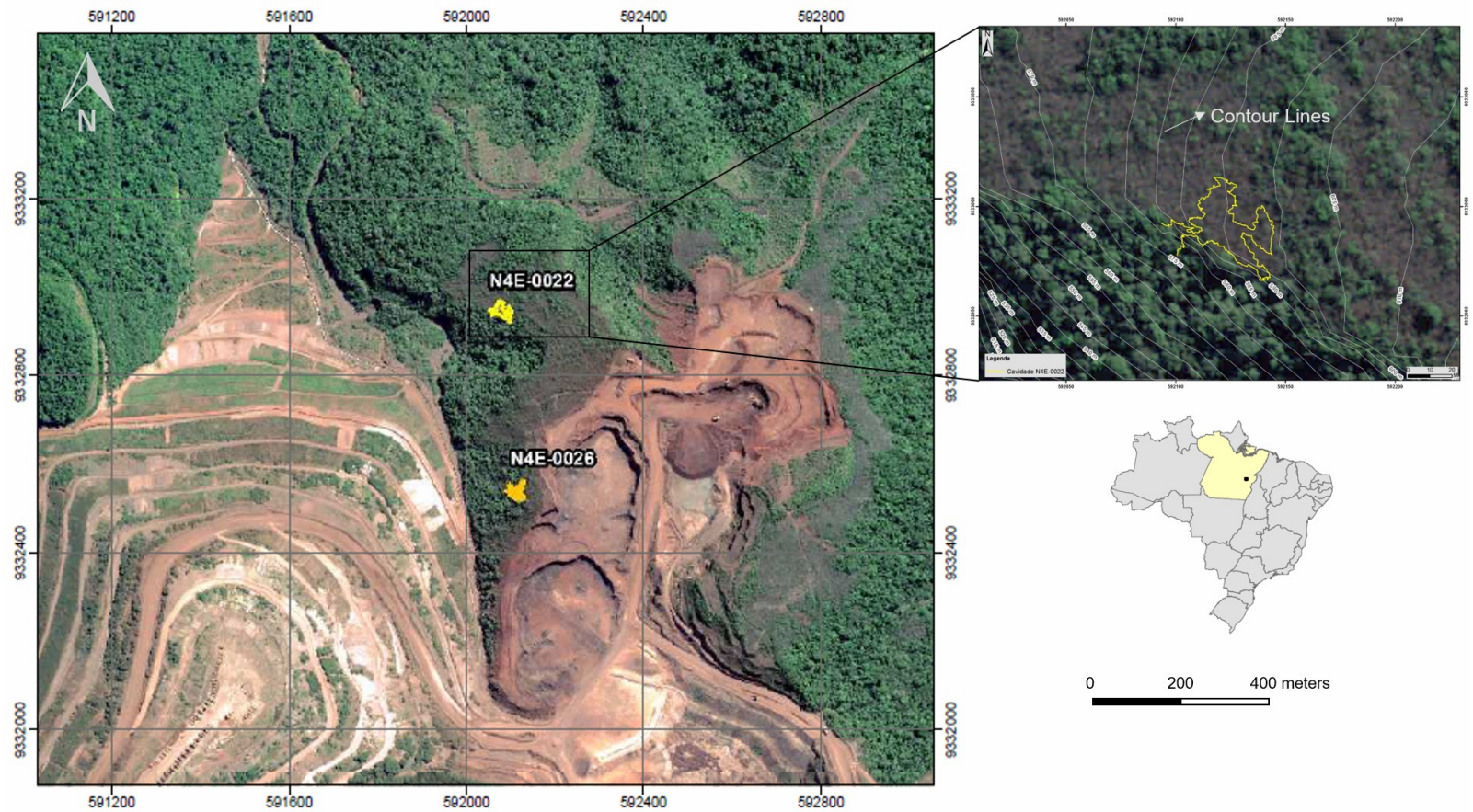

Figure 1 - Location of study area and selected cave N4E-0022 (floor plan projected on the ground). N4EN iron mine, Carajás Complex, Pará, Brazil.
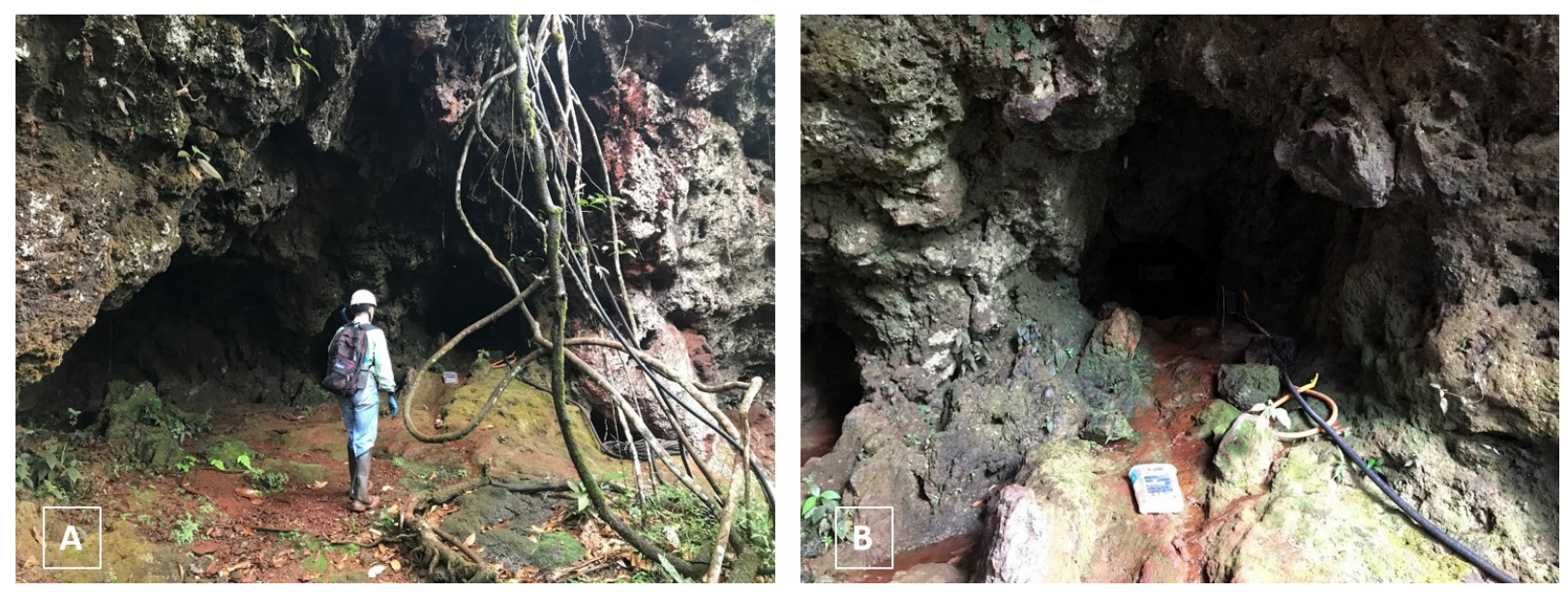

Figure 2 - A: View of N4E-0022 cave entrance; B: Cave access conduit.

\section{GEOLOGICAL SETTINGS Regional Geology}

The Carajás Province represents the oldest and best-preserved crustal portion of the Amazon Craton (Vasquez \& Rosa-Costa, 2008). The Province is in the southeast of Pará state, Brazil, and contains one of the largest mineral provinces on the planet. Originally, this province integrated the Central Amazon Province (Amaral, 1974), related to the Transamazonic Cycle.

This article considered the geological definition adopted by Santos (2003). That author separated the Carajás Province in the Rio Maria domain, to the south, and Carajás domain, to the north. The boundary between the two domains, was defined based on magnetometric anomalies, not coincident with geological contacts.

The Carajás domain consists of a high-grade association of Mesoarchean basement, Neoarchean metavulcan-sedimentary sequences and mafic-ultramafic associations (greenstone belts). Associations of compositionally evolved Neoarchean granites, are contemporaneous with the metavulcan-sedimentary sequences. A sedimentary formation from the Neoarquean 


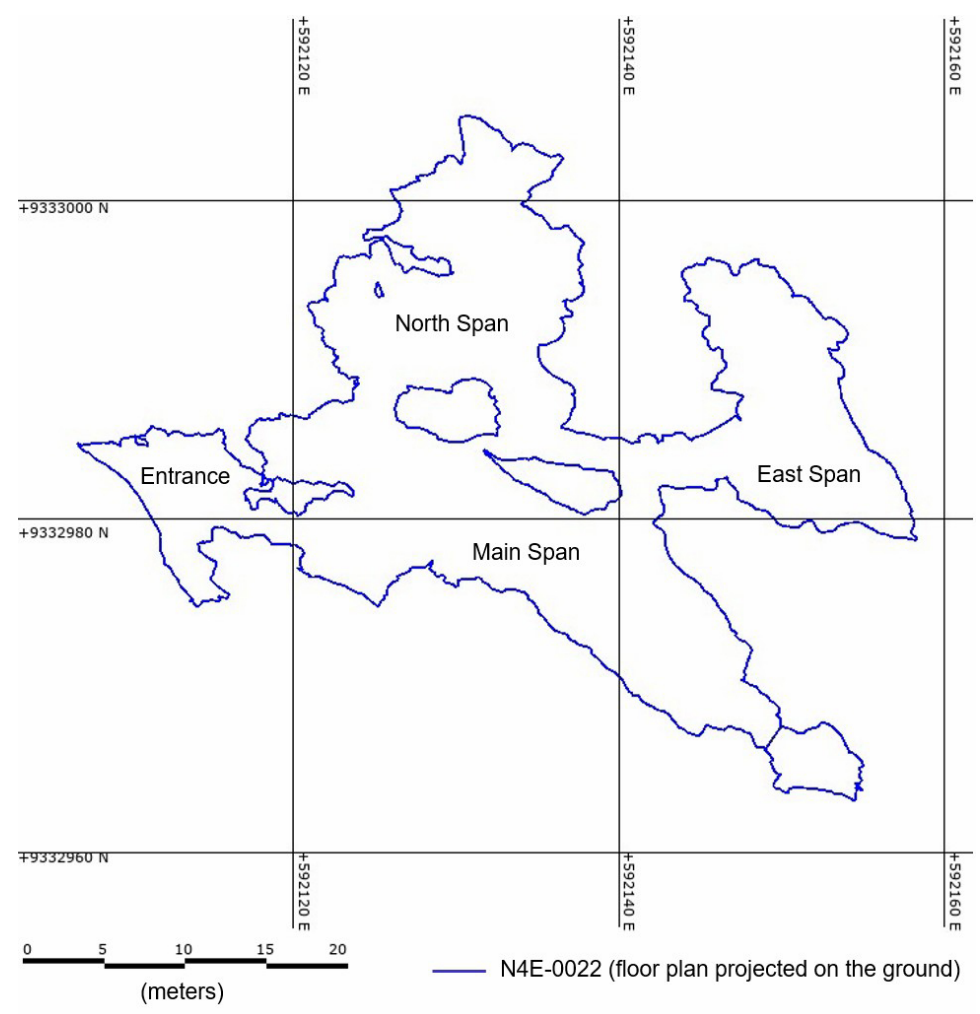

Figure 3 - N4E-0022 cave floor plan and its entrance and spans (main, north and east).

continental shelf covers the greenstone belts. In this domain, the Paleoproterozoic tectonic associations are siderian mafic-ultramafic bodies (Araújo \& Maia, 1991) and orosinian type A granites (Dall'Agnol et al., 2006).

The iron deposits of Serra dos Carajás are related to the metavulcan-sedimentary sequence of Grão Pará Group $( \pm 2.76$ Ba, according to Machado et al., 1991), Itacaiúnas Supergroup. This group consists of a thick sequence of upper and lower volcanic rocks (Parauapebas Formation, Meireles et al., 1984) and iron ore (Carajás Formation, CVRD / CMM, 1972). The jaspilites are formed by alternating bands of iron minerals (hematite and magnetite) and jasper $\left(\mathrm{SiO}_{2}\right)$. The occurrence of jaspilites in a wide area allowed the development of a region rich in high-grade iron ore (>65\% Fe).

\section{Weathering Profile}

The weathering profile of iron rocks has already been approached by different authors such as Dorr (1964), Eichler (1967), Chemale Jr. et al. (1987), Rosière \& Chemale Jr. (2001), Costa (2007), and others. According to Rosière \& Chemale Jr. (2001), the lateritic profile varies from a few meters up to tens of meters and protects the underlying ferrous formations from the oxidation and hydration process, allowing more effective $\mathrm{SiO}_{2}$ leaching.

Gonçalves et al. (2016) presented research on the lateritic profile in the N4EN region, Carajás Complex. They described the composite lateritic profile, from top to bottom, as a lateritic crust, a transition horizon, both with irregular contacts and sometimes without clear definition, and a saprolite horizon, with easy contact definition that evolves in depth into a preserved banded iron formation (Fig. 4).

The lateritic crust, or duricrust, is a hardened surface formation resulting from the evolution of the landscape and the relief. This formation is directly linked to polycyclic weathering and pedogenic processes. This superficial portion, also known as "canga", receives denominations according to the degree of resistance (uniaxial compressive strength) and the weathering degree, its thickness ranging from 2 to 15 meters. The detailed geological-geotechnical mapping of the study area identified this horizon as ferruginous lateritic crust (CLF).

The transition horizon, located between the saprolite horizon and the lateritic crust, presents irregular thickness $(0,5$ to 15 meters), low geotechnical condition, high permeability, structural/textural weakness. These characteristics could 
contribute to an erosion of this horizon, if it is not maintained by the hardened crust. The pores and the cavernous texture give this horizon a particular condition of low density (Maurity \& Kotschoubey, 1995) which favor the development of caves in iron environment. The detailed geological-geotechnical mapping identified this horizon as lateritic iron formation (FFL).

The last horizon is a thick saprolite zone with weak geotechnical resistance (Gonçalves et al., 2016). This horizon can reach up to 400 meters deep and presents partially weathered rock with preservation of the original texture. Usually, this saprolite horizon has a yellowish and whitish color, clayey, kaolinite constitution and contribution of aluminum, iron oxides and hydroxides. Contact with the transition horizon is usually abrupt or slightly irregular.

\section{Drillhole Correlation with Geophysical Well Logging}

The geological-geotechnical mapping was complemented by 8 diamond drillholes (SN4-FD00069 to SN4-FD00076) an average depth of 50 meters, located in the surroundings of cave N4E-0022.

The borehole geophysical data included: caliper (records the drillhole diameter), gamma-gamma (measures bulk density of the formation near the borehole) and natural gamma (identifies lithological boundaries).

The lithologic description from examination of cores showed four lithotypes: ore canga $(\mathrm{CH})$, chemical canga $(\mathrm{CQ})$, mafic rocks (MD) and friable hematite (HF).

Figure 5 shows an example of one of the geophysical well loggings and its respective lithologic description from examination of cores.

The information obtained from the weathering profile, the geophysical well logging inside the drilling rod, the lithologic description of drillhole and the geostructural mapping in the N4E-0022 cave surroundings were correlated with the geoelectric signatures and served to guide the following interpretations.

\section{METHODOLOGY}

The success in geophysical prospecting depends on the ability to reach the target as well as on the use of appropriate vertical resolution for each proposed problem. It was proposed, for the present study, an integration between the electrical resistivity method and the lateritic profile (detailed by drillhole geophysical logging and conventional mapping) in order to identify physical parameters for construction of the data set and specific geoelectrical signatures that could be correlated with lithostructural features.

\section{Electrical Resistivity}

The Electrical Profiling technique, used for this study, is applied when the target of interest is the study of both lateral and vertical resistivity variation. This method of geophysical prospecting employs a direct electric current based on artificial emission introduced into the ground through two current electrodes ( $A$ and $B$ ) and measured by an ammeter. The potential generated in other two potential electrodes ( $\mathrm{M}$ and $\mathrm{N}$ ) in the vicinity of the current flow is measured by a voltmeter (Fig. 6).

The electrodes are inserted into the ground to improve the electrical connection and its configurations (arrays) give the method great versatility. For very resistive terrains, the soil must be soaked with saline solution and/or with bentonite. The difficulty in making good electrical contact with the soil is the main deficiency of the geoelectrical methods (Braga, 1997).

According to Oldenburg \& Jones (2007), the resistivity (and its inverse, conductivity) of soils and rocks can be affected by: mineralogical composition, porosity, hydraulic permeability, moisture content, dissolved electrolyte concentration, temperature and phase of the interstitial fluid, amount of colloid composition (clay content) and geophysical acquisition direction (anisotropy).

The apparent resistivity value $\rho_{a}$ can be calculated using the following equation (Eq. 1):

$$
\rho_{a}=K \frac{\Delta V}{I}
$$

Where $\Delta \mathrm{V}$ is the potential difference (volts), I is the electric current (amperes) and $\mathrm{K}$ is the geometric coefficient between the four electrodes. Mathematically, the parameter $\mathrm{K}$ may be expressed by (Eq. 2):

$$
K=2 \pi\left(\frac{1}{A M}-\frac{1}{B M}-\frac{1}{A N}+\frac{1}{B N}\right)^{-1}
$$

$\mathrm{AM}, \mathrm{BM}, \mathrm{AN}$ and $\mathrm{BN}$ correspond to the distance between the current electrodes and the point at which the potential is measured.

The variable $\rho_{a}$ expresses the results of the measurements in the majority of the geoelectrical methods and, therefore, it forms the basis for the final interpretations. The unit of the apparent resistivity is given in ohm.m. 


\section{Thickness (meters)}
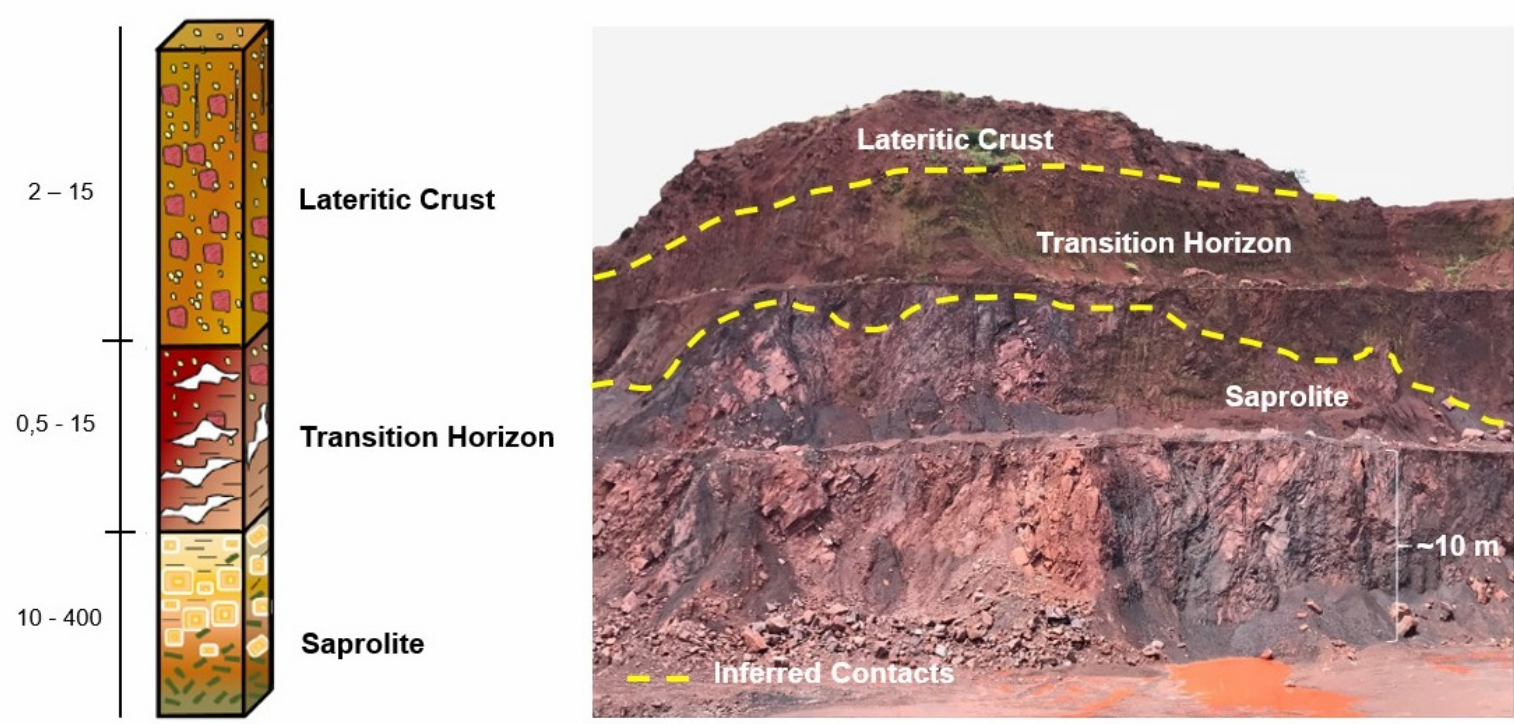

Figure 4 - Illustrative scheme of a typical lateritic profile in N4EN mine, Carajás Complex. The photograph shows the qualitative correlation of an exposed bench in N4EN mine pit with the typical lateritic alteration profile. Adapted from Gonçalves et al. (2016).

\section{Geoelectric survey data, processing and inversion routine}

For the N4E-0022 cavity, five resistivity sections were obtained (Fig. 7) overlaying the cave N4E-0022 (three in the SW-NE direction and two in the SE-NW direction). The sections were spaced 10 meters away from one another and the average length of the sections were about 70 meters.

The equipment used was the electrical resistivity meter SAS 4000 (ABEM), composed of a control unit, a selector unit, a battery, electrodes with metal rods and cables. Such equipment has the capacity for 64 electrodes, being able to address a maximum of 10 electrodes simultaneously, 2 current and 8 potential electrodes.

The electrode spacing was 1.40 meters considering the size of the conduits and of the spans, as well as the required resolution. Because of the rugged terrain and operational impossibilities, some electrodes had to be ignored (skipped) in the most critical portions. However, this does not compromise the data generated, considering the large volume of points satisfactorily collected.

The softwares used in the processing, analysis and interpretation of the data were RES2DINV (inversion and processing of electrical data), Surfer and Voxler (image processing, point cloud and other assemblies) and Leapfrog Geo (numerical modeling and three-dimensional visualization).
The RES2DINV software uses the smoothness-constrained Gauss-Newton least-squares method inversion technique to produce the resistivity model of the subsurface from the apparent resistivity data. The conventional Gauss-Newton method is recommended for areas with large resistivity contrasts, and it does give slightly better results. The optimization method basically tries to reduce the difference between the calculated and measured apparent resistivity values by adjusting in the automatic mode the resistivity of the model blocks (Loke, 2001). The inversion result is shown in the Figure 8.

Array tests were conducted in the initial phases of the project to search for the best acquisition array. They were conducted in a section near the cave N4E-0022 with the following arrays: Dipole-Dipole, Schlumberger and Wenner. The electrode array chosen for the Electrical Resistivity acquisition was the Dipole-Dipole (DDP) because of its satisfactory signal-to-noise ratio (SNR) and research depth versus lateral resolution.

\section{RESULTS}

The analysis of the resistivity sections considered the profile differentiation by resistivity magnitude in zones of high values in resistivity model (ZAR), whose values are above $2.7 \times 10^{3} \mathrm{ohm} . \mathrm{m}$, and zones of low values in resistivity model (ZBR), whose values are below 760 ohm.m, approximately (Fig. 9). Intermediate values between those described above were associated with intermediate resistivity zones (ZIR). 


\section{SN4-FD00071}

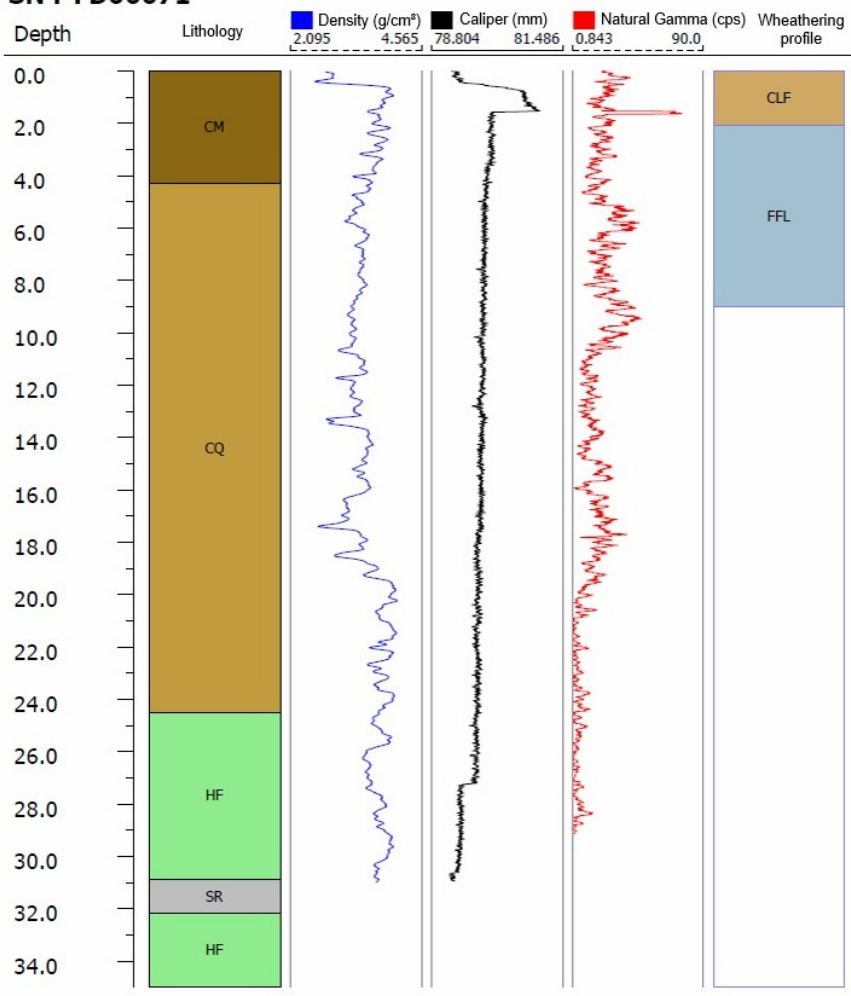

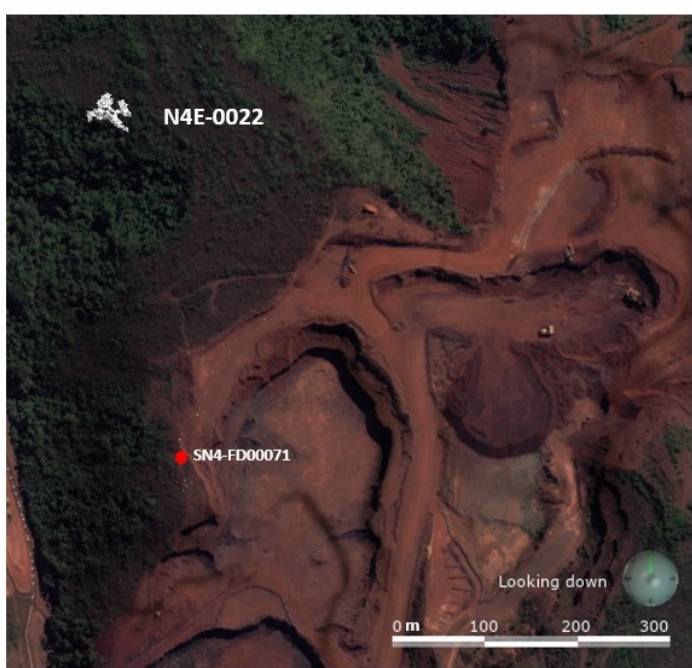

\section{LEGEND}

- SN4-FD00071 drillhole

\section{Drill Hole Description}

\begin{tabular}{|c|c|}
\hline $\mathrm{CM}$ & Ore Canga \\
\hline $\mathrm{CQ}$ & Chemical Canga \\
\hline SR & No Recovery \\
\hline $\mathrm{HF}$ & Friable Hematite \\
\hline
\end{tabular}

Figure 5 - Geophysical and lithologic logs of drillhole SN4-FD00071, in the N4E-0022 cave surroundings. The geophysical log includes caliper, density and natural gamma measurements and the weathering profile shows the average thicknesses obtained in bench detail mapping.

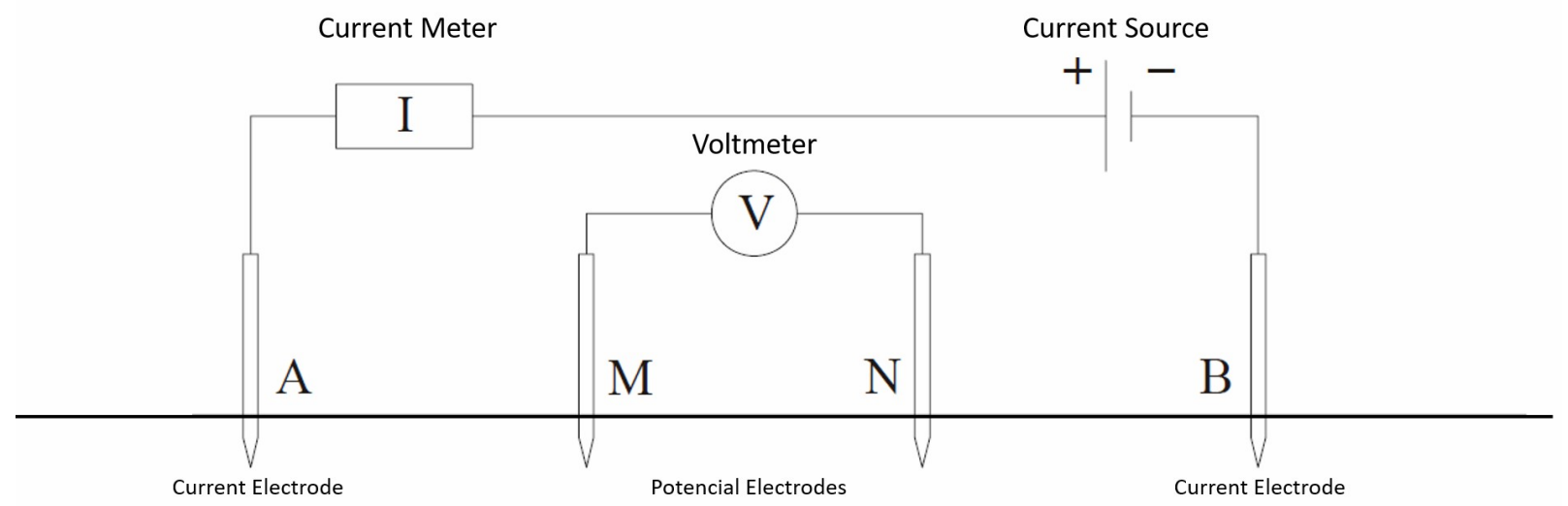

Figure 6 - Electrical profiling technique. Scheme of acquisition of electrical resistivity method: two current electrodes (A and B) and two other potential electrodes (M and N). 


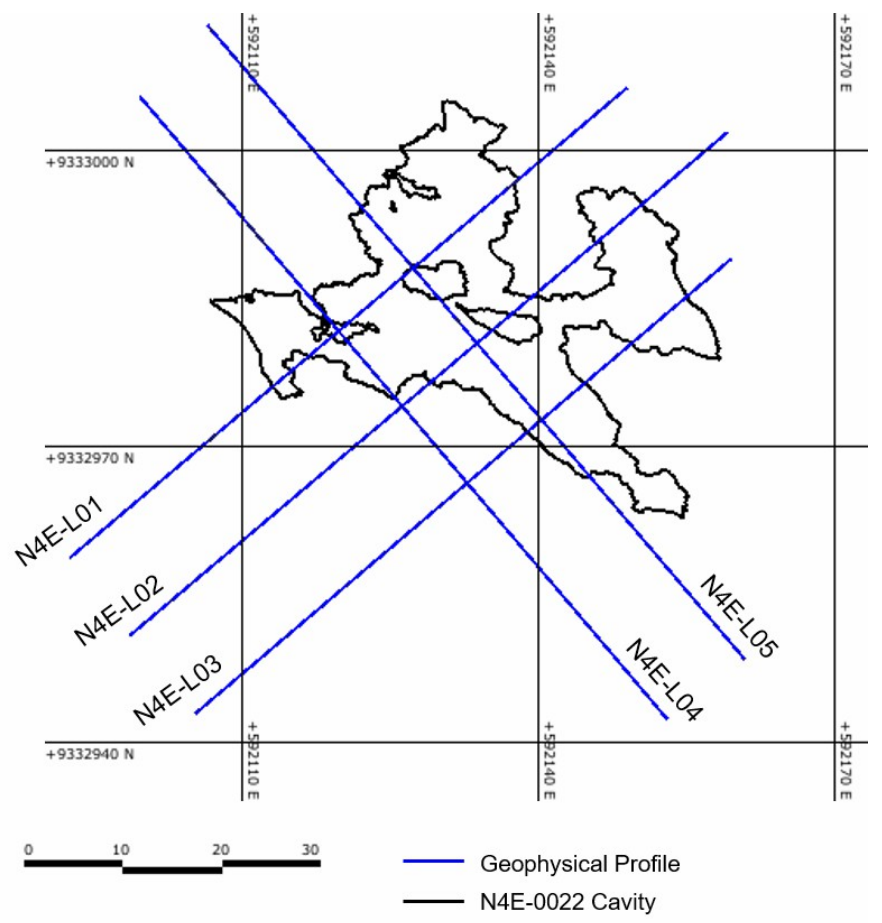

Figure 7 - Electrical resistivity lines in the study area, overlaying the cave N4E-0022.
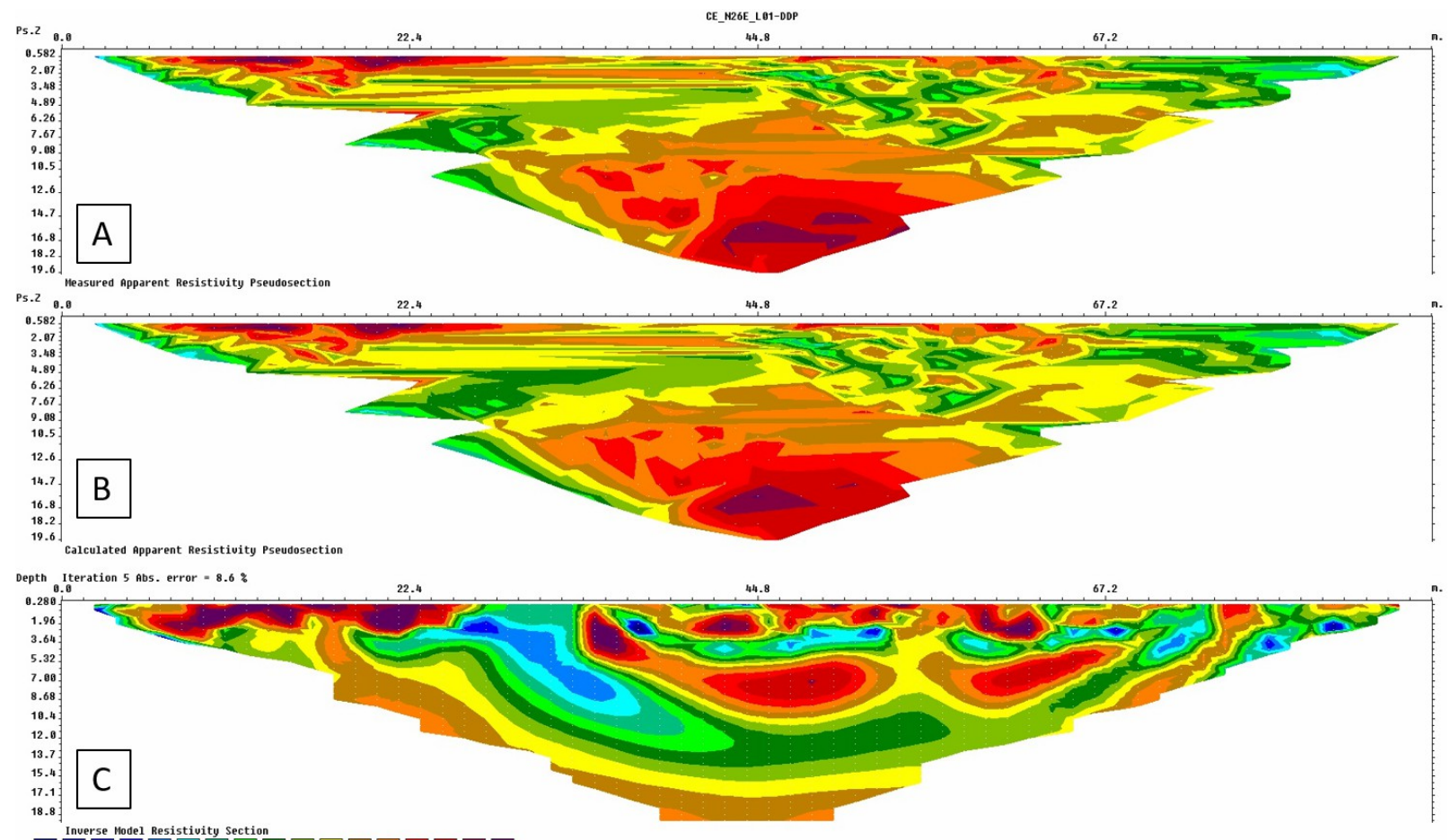

$\square_{213}^{\text {Inverse Hodel Resistivity Section }} \underset{354}{{ }_{598}} \square_{982} \square_{2718} \square_{4523} \square_{7527}$

Unit electrode spacing $1.40 \mathrm{n}$

Figure 8 - Electrical resistivity inversion result. A: Measured apparent resistivity pseudosection; B: Calculated apparent resistivity pseudosection; C: Inverted electrical model. 


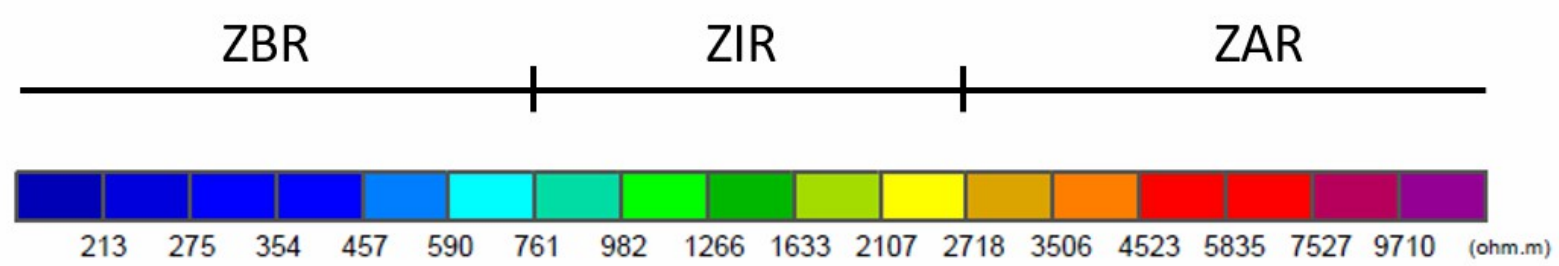

Figure 9 - Chromatic scale for resistivity and its division in zones of high values in resistivity model (ZAR), zones of low values in resistivity model (ZBR) and intermediate resistivity zones (ZIR).

\section{Geoelectric Signatures}

The high resistivity zones (above $2.7 \times 10^{3} \mathrm{ohm} . \mathrm{m}$ ) form a relatively continuous horizon in the upper portion of the electrical section (e.g. resistivity section N4E-L03 in Fig. 10) ranging from 1 meter to 3 meters in thickness. This horizon is related to the laterization process of rocks, and matches the top layer of the lateritic profile (lateritic crust). Its high roughness is closely associated with the macroporosity resulting from its genesis. Such pores are partially or completely air-filled, which contributes to an increase in the resistivity model values of this horizon.

The horizon below (transition horizon), can reach up to 19 meters in thickness, and shows a reduction in resistivity model values (between 760 and $2.7 \times 10^{3}$ ohm.m). This horizon is characterized by greater probability of cave development. The predominance of clayey sediments, the slightly sloped floor and the absence of flow outlets in the cave are responsible for the accumulation of water and moisture, mainly due to the porous and cavernous rock texture. This geophysical horizon is characterized by the reduction in the values of resistivity sections and can be correlated to the lower density transition horizon of the lateritic profile.

The basal horizon is present in the sections and characterized by the zones of high values in resistivity model (above $7.5 \times 10^{3}$ ohm.m). This horizon can be correlated to the saprolite horizon of the lateritic profile and the propensity for fresh rock grows in proportion to the depth. The increase in rock preservation (friable hematite) in depth and the presence of increasingly tight fractures make this horizon more resistive.

Figure 10 shows the resistivity model N4E-L03 and its correlation with the typical lateritic profile (lateritic crust, transition horizon and saprolite).

The interpretations were extrapolated to all the geophysical sections through a graphical analysis of the horizons. After the analysis and interpretation of the $2 \mathrm{D}$ geophysical sections, the files were imported into the specific modeling software Leapfrog Geo.
The software Leapfrog Geo allows for three-dimensional visualization of the geophysical sections obtained (Fig. 11A) as well as construction of diagram blocks consistent with the typical lateritic profile of the region. The following steps were performed and summarize the numerical modeling development:

1) The contacts between the geophysical horizons explicitly demarcated in the 2D sections of electrical resistivity profile were imported into the software (Fig. 11B);

2) The upper and lower contacts, previously interpreted, were transformed into planar surfaces and related to lower separation of transition horizon - saprolite (Fig. 11C) and upper separation of lateritic crust - transition horizon (Fig. 11D);

3) Then, dynamic models referring to saprolite (Fig. 11E), transition horizon (Fig. 11F) and lateritic crust (Fig. 11G) were individually generated through specific interpolators using a radial basis function for modeling;

4) The result modeled by the software (Fig. 11H) shows, in a schematic way, the satisfactory approximation with the local reality and with the existent models for the lateritic profile of the region.

The block diagrams constructed from the numerical modeling of geoelectrical data were consistent with the lateritic profile. The depths of each interpreted geophysical horizon were perfectly compatible with the detailed description of weathering horizons in the mine pit, as expected.

The geoelectrical data were correlated with direct detailed mapping near the cave N4E-0022, including the lithologic description of the drillhole and the geophysical well logging. The correlations (Fig. 12) between direct and geoelectrical data were very close for all horizons interpreted. The drillhole chosen for the correlations was SN4-FD00071. 


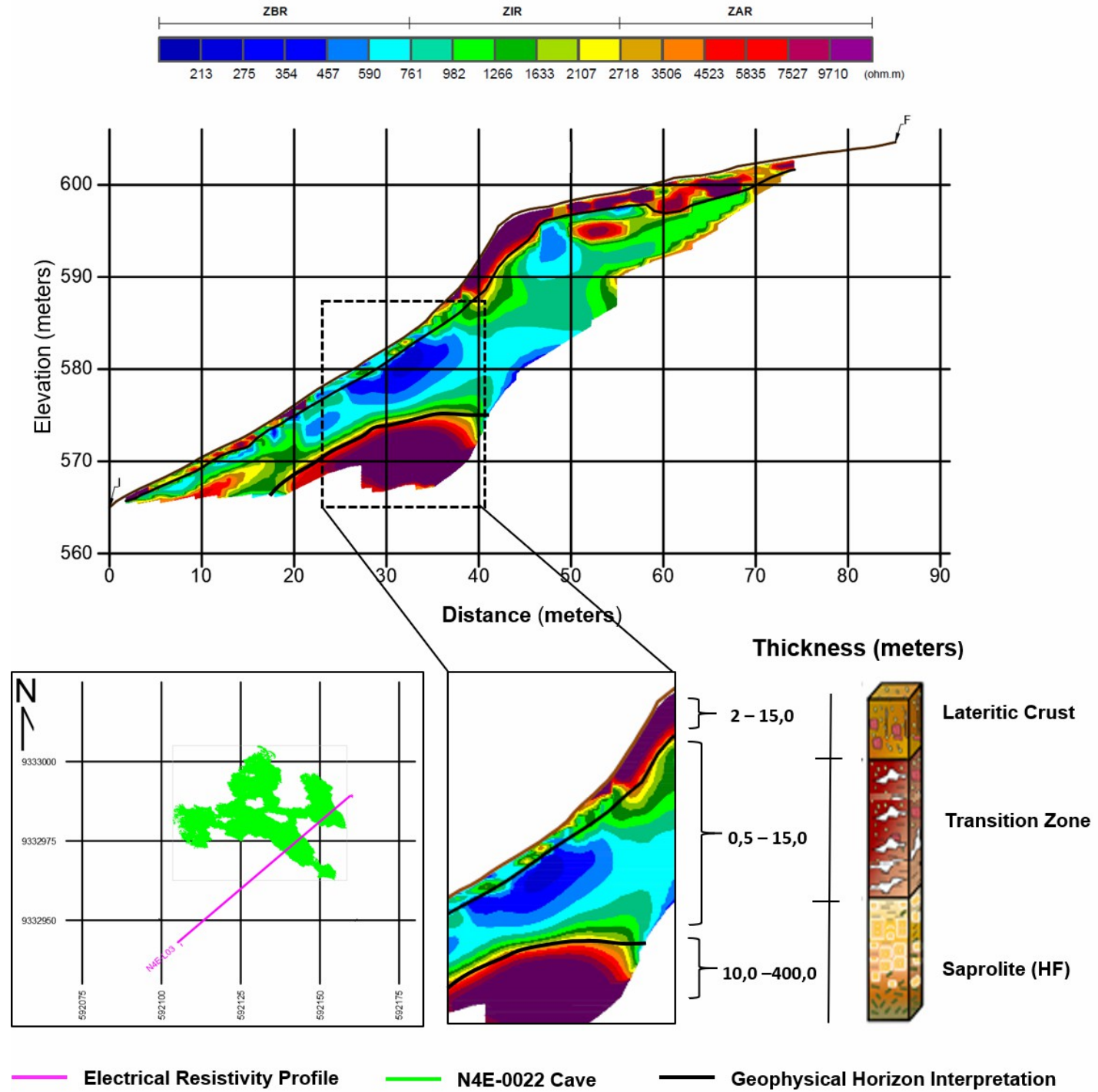

Figure 10 - Resistivity model N4E-L03 overlaying cave N4E-0022 and its correlation with the lateritic profile. The high resistivity zones in the upper portion of the electrical section are related to the laterization process of rocks, and matches the top layer of the lateritic profile (lateritic crust). The horizon below (transition horizon) shows a reduction in resistivity model values. The basal horizon is characterized by the zones of high values in resistivity model and can be correlated to the saprolite horizon of the lateritic profile.

The top layer of detailed mapping near the cave N4E-0022, lateritic crust, showed reasonable similarity with the geophysical $\log$, which was highlighted by the increase in density values (ranging from $3.2 \mathrm{~g} / \mathrm{cm}^{3}$ to $3.9 \mathrm{~g} / \mathrm{cm}^{3}$ and average $3.6 \mathrm{~g} / \mathrm{cm}^{3}$ ). This horizon also showed good correspondence with the geoelectrical profile, which defined a continuous horizon in the upper portion with high resistivity zones. The lithologic descriptions of drillhole defined the top layer as ore canga, characterized by the presence of compact rock (e.g. goethite, magnetite and hematite), reflecting the high-density values observed in the geophysical well logging.

The transition horizon of detailed mapping also showed adequate similarity with the geophysical $\log$ and matched the reduction in the density values (ranging from $2.6 \mathrm{~g} / \mathrm{cm}^{3}$ to $3.6 \mathrm{~g} / \mathrm{cm}^{3}$ and average $3.3 \mathrm{~g} / \mathrm{cm}^{3}$ ). According to Maurity \& Kotschoubey (1995), the pores and the cavernous texture give this horizon a particular condition of low density, which favor the development of iron caves. This horizon was also adequately similar to the geoelectrical profile, characterized by the reduction 
(A)

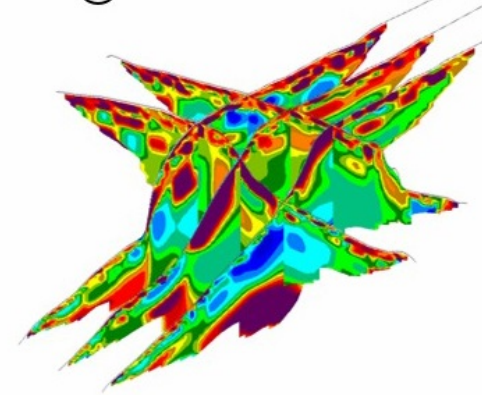

(C)

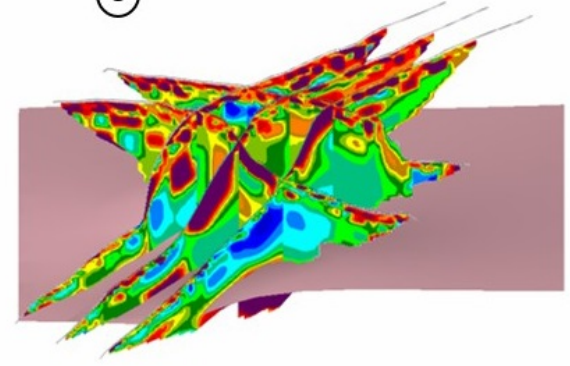

(E)

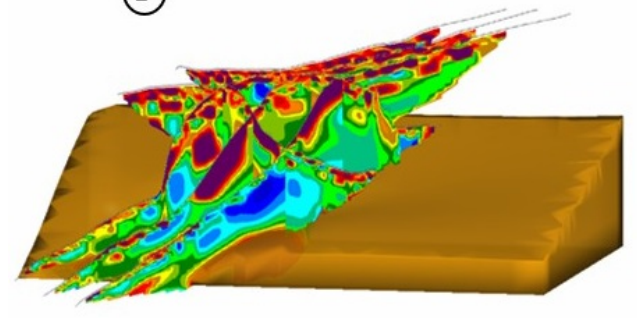

(G)
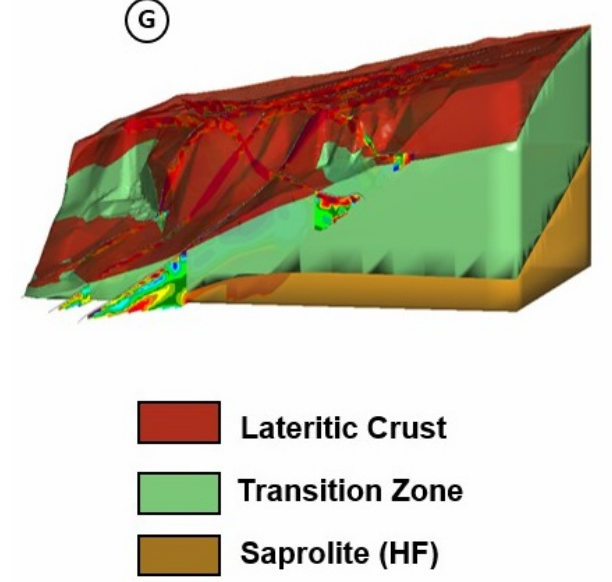

\section{Lateritic Crust}

Transition Zone

Saprolite (HF)
(B)
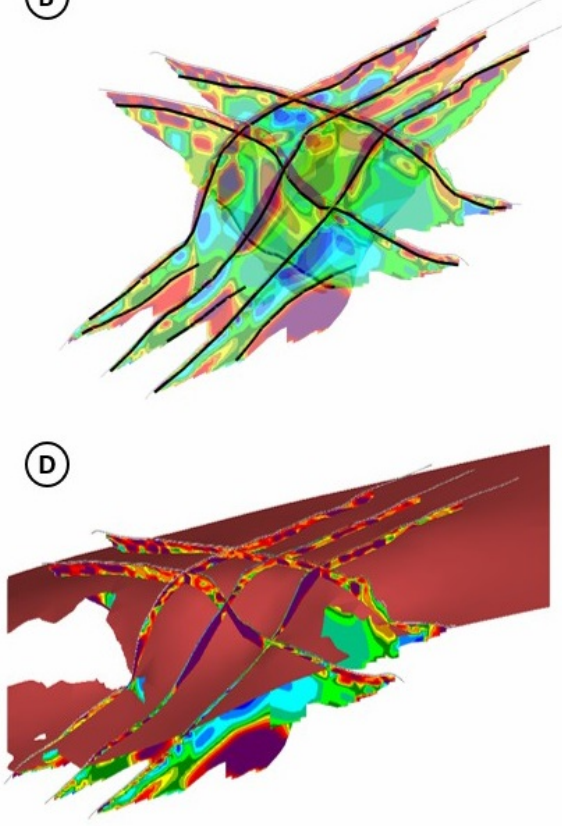

○
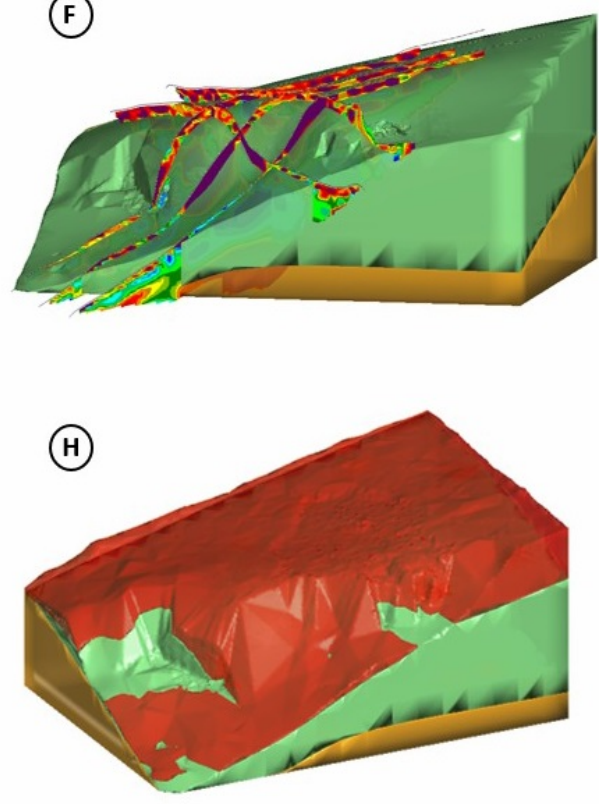

$\begin{array}{lllll}0.0 \quad 12.5 & 25.0 & 37.5 & 50.0 & \\ \end{array}$

Figure 11 - Implicit modeling process of the geoelectrical data acquired in N4E-0022 cavity. A: Resistivity sections 2D; B: Explicit delimitation of geophysical contacts; C: Modeling the lower surface related to the contact transition horizon - saprolite; D: Modeling of the upper surface related to the contact canga - transition horizon; E: saprolite model (HF); F: Transition horizon model; G: lateritic crust model; H: Implicit model for the lateritic profile of the N4E-0022 region from geophysical data. 


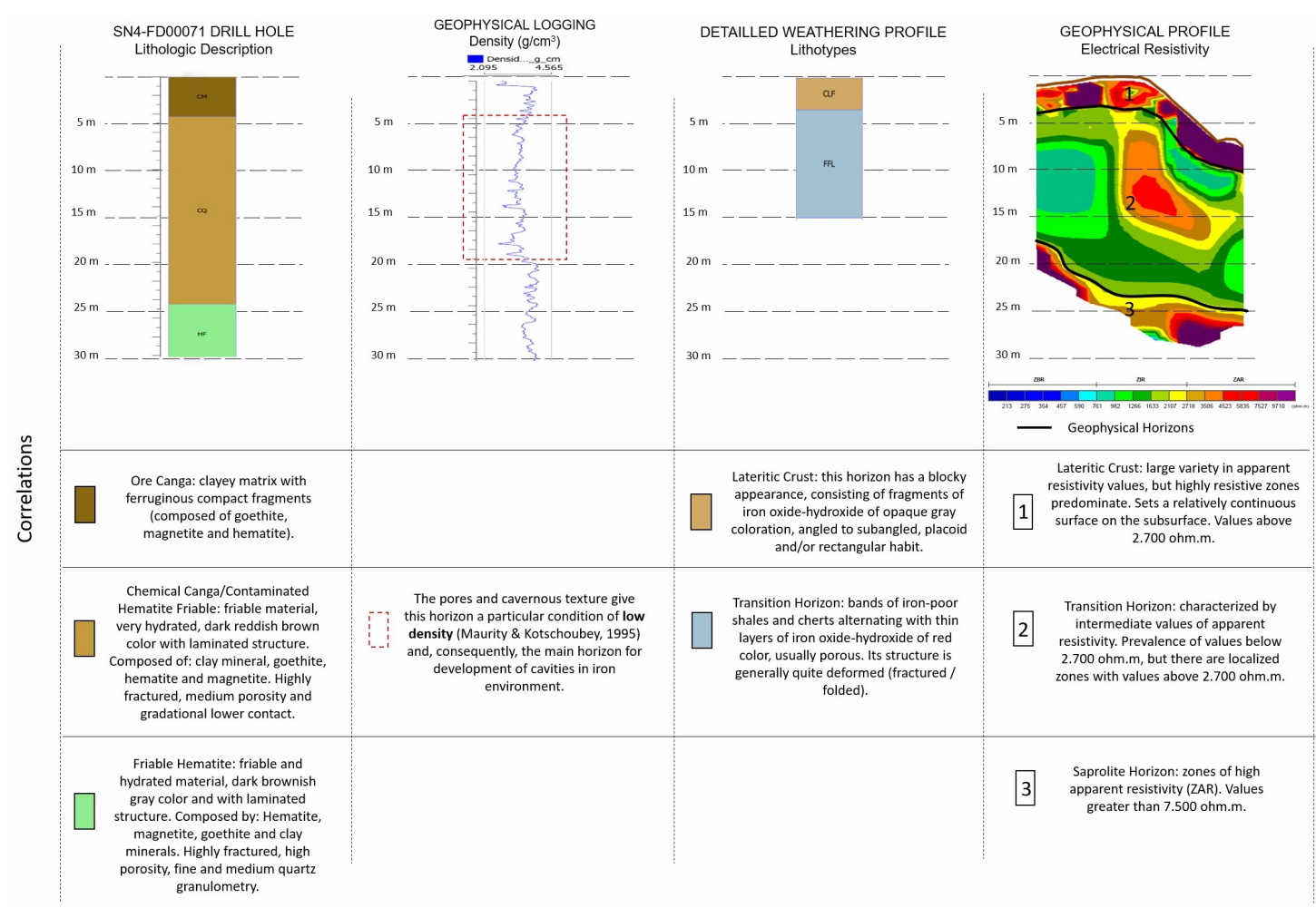

Figure 12 - Correlations between direct data (lithologic description of drillhole, geophysical well logging, detailed weathering profile) and geoelectrical signatures.

in resistivity model values. The lithologic descriptions of drillhole defined the middle layer as chemical canga and contaminated friable hematite. The presence of different properties (e.g. hydrated material, clay, porosity and mineral such as hematite, magnetite and goethite) confirms the transitional character of this horizon.

The saprolite horizon, located in the basal portion of the resistivity section, presents its limit according to the lithologic description of drillhole (friable hematite). The presence of characteristics originating from the fresh rock (e.g. laminated structure) confirms the interpretation of the geoelectrical profile, which shows zones of high values in resistivity model. This horizon also showed reasonable association with the geophysical $\log$, characterized by the high-density values return after 20 meters deep (ranging from $2.9 \mathrm{~g} / \mathrm{cm}^{3}$ to $4.1 \mathrm{~g} / \mathrm{cm}^{3}$ and average $\left.3.8 \mathrm{~g} / \mathrm{cm}^{3}\right)$.

\section{CONCLUSION}

The use of near-surface geophysics, such as the electrical resistivity method, applied to iron caves has shown exponential growth because of the increasing demand from the economic sector as well as from compliance with issues related to environmental licensing. The near-surface geophysical methods generated continuous images in the region surrounding cave N4E-0022 and therefore, proved to be better for the purposes of elucidating lateritic horizons, especially in places where applying conventional methods is difficult.

The resistivity sections (N4E-L01 to N4E-L05) individualized three main horizons strongly correlated with the typical lateritic profile in the N4EN mine pit: lateritic crust, transition horizon and saprolite horizon. The relationship between geoelectrical profiles and direct investigations (drillholes and geophysical well logging) served to mark the geoelectrical signatures to the site's speleological reality, providing technical inputs for assertive models.

The top layer of the detailed mapping near the cave N4E-0022 was defined as lateritic crust. The lithologic descriptions of the drillhole defined the top layer as ore canga, characterized by the presence of compact rock. In both associations, the results showed good similarity with the geophysical log, and with the geoelectrical profile, which defined a continuous horizon in the upper portion with high resistivity zones. 
The transition horizon, located in the middle portion of the resistivity section, showed good association with the lithologic descriptions and detailed weathering profile. This horizon also showed adequate similarity with the geophysical log and matched the reduction in the density values. This reduction represents an important physical property because, according to Maurity \& Kotschoubey (1995), the pores and the cavernous texture give this horizon a particular condition of low density, which favors the development of iron caves.

The saprolite horizon, located in the basal portion of the resistivity profile, is characterized by the high-density values return. This horizon showed good association with the geophysical log and lithologic log of drillholes.

The geoelectrical data were inserted in a numerical modeling software (Leapfrog $\mathrm{Geo}$ ) to generate three-dimensional diagrams representative of the existing lateritic horizons. The models were easily correlated with the lateritic profile and the contacts were very consistent.

This wide spatial sampling was done in a non-invasive way and may contribute, in the future, to a significant reduction in the number of traditional instruments needed, as well as for a more focused monitoring of interesting areas and/or zones with structural weakness.

\section{ACKNOWLEDGMENTS}

The authors would like to express their sincere acknowledgments to Vale S.A., Núcleo de Geotecnia da Escola de Minas (NUGEO), Universidade Federal de Ouro Preto (UFOP), Neogeo Geotecnologia Ltda., Centro de Pesquisa em Geofísica Aplicada (CPGA) and Universidade Federal do Rio de Janeiro (UFRJ).

\section{REFERENCES}

AMARAL G. 1974. Geologia Pré-cambriana da Região Amazônica. Tese (Livre Docência) - Instituto de Geociências, Universidade de São Paulo. São Paulo, SP, Brazil. 212 pp.

ARAÚJO OJB \& MAIA RGN. 1991. Serra dos Carajás, Folha SB-22-Z-A. Final Report. CPRM, Rio de Janeiro, RJ, Brazil.136 pp.

BARBOSA MR. 2018. Geofísica Espeleológica - Metodologia para Aplicação de Eletrorresistividade na Investigação de Instabilidade Litoestrutural de Teto em Cavidades Ferríferas. Cavidade N4E-0026, Mina N4EN, Carajás, PA, Brasil. Doctorate Thesis. Programa de Pós-Graduação em Geologia, Universidade Federal do Rio de Janeiro. Rio de Janeiro, RJ, Brazil. 92 pp.

BARBOSA MR, DE PAULA RG, BRAGA MA, BRANDI IV, CLAUVER C, MATOS J \& SEBASTIÃO C. 2016a. Aplicação do Método Ground
Penetrating Radar (GPR) no Mapeamento Geoestrutural de Cavidades Naturais Subterrâneas em Terrenos Ferríferos - Estudo de Caso da Mina N4E, Carajás. In: VII Simpósio Brasileiro de Mecânica das Rochas SBMR. Belo Horizonte, MG, Brazil. ABMS (Associação Brasileira de Mecânica dos Solos e Engenharia Geotécnica).

BARBOSA MR, DE PAULA RG, BRAGA MA, BRANDI IV, CLAUVER C, MATOS J \& DIAS LSO. 2016b. Métodos Geofísicos Aplicados a Coberturas Lateríticas com Feições Pseudocársticas na Mina de Ferro N4E, Carajás. In: VII Simpósio Brasileiro de Geofísica - SimBGf. Ouro Preto, MG, Brazil. SBGf.

BARBOSA MR, BRAGA MAS, BRANDI IV, DE PAULA RG, ARAÚJO RN, PROSDOCIMI GAS \& DIAS LSO. 2017. Geofísica Rasa na Investigação Geológica-Geotécnica de Cavidades Naturais Subterrâneas na Mina de Ferro N4E, Carajás. In: 15th International Congress of the Brazilian Geophysical Society. Rio de Janeiro, RJ, Brazil. SBGf.

BRAGA ACO. 1997. Métodos geoelétricos aplicados na caracterização geológica e geotécnica - Formações Rio Claro e Corumbataí, no município de Rio Claro - SP. PhD Thesis, Instituto de Geociências e Ciências Exatas, Universidade Estadual Paulista. SP, Brazil. 169 pp.

CARDOSO LH. 2016. Investigação geofísica na prospecção de cavidades naturais em litotipos ferríferos na região de Mariana, sudeste do Quadrilátero Ferrífero, Brasil. Master Dissertation (Mestrado em Engenharia Mineral) - Escola de Minas (Departamento de Engenharia de Minas - DEMIN), Universidade Federal de Ouro Preto (UFOP). Ouro Preto, MG, Brazil. 102 pp.

CARSTE - CARSTE CONSULTORES ASSOCIADOS LTDA. 2013. EIA Global Serra Norte. Relatório Interno Vale S.A. de Diagnóstico e Análise de Relevância. Belo Horizonte, MG, Brazil. 300 pp.

CHEMALE JR F, QUADE H \& SANTANA FC. 1987. Economic and structural geology of the Itabira Iron District, Minas Gerais, Brazil. Zbl. Geol. Paläontol., VI(7/8): 743-752.

COSTA LP. 2007. Caracterização das sequências metavulcanossedimentares da porção leste da Província Mineral Carajás, Pará. Master Dissertation, Departamento de Geologia, Universidade Federal de Minas Gerais. Belo Horizonte, MG, Brazil. $113 \mathrm{pp}$.

CVRD/CMM. 1972. Distrito Ferrífero da Serra dos Carajás. In: $26^{\circ}$ Congresso Brasileiro de Geologia. Resumos das Comunicações. Belém, PA, Brazil. SBG - Núcleo Norte, 2: 78-80.

DALL'AGNOL R, OLIVEIRA MA, ALMEIDA JAC, ALTHOFF FJ, LEITE AASL, OLIVEIRA DC \& BARROS CEM. 2006. Archean and Paleoproterozoic granitoids of the Carajás Metallogenic Province, eastern Amazonian Craton. In: Symposium on Magmatism, Crustal Evolution, and Metallogenesis of the Amazonian Craton. Belém, PA, Brazil. PRONEXUFPA/SBG-NO, 97-150. 
DORR JVN. 1964. Supergene iron ores of Minas Gerais, Brazil. Econ. Geol., 59(7): 1203-1240.

EICHLER J. 1967. Das physikalische Millieu bei der Verwitterung von Itabiriten in Minas Gerais/Brasilien. Chemie der Erde, 26(2): 119-132.

FRANCSIK T \& NYARI Z. 1999. Processing of geoelectric cavity detection data using deconvolution filtering method. In: 61st Conference and Technical Exhibition. Helsinki, Finland. EAGE.

GAMA MFP, BARBOSA MR, BRANDI IV \& BRAGA MAS. 2018. Caminhamento elétrico aplicado ao mapeamento de cavidades naturais em minério de ferro, Carajás (PA). In: $49^{\circ}$ Congresso Brasileiro de Geologia. Rio de Janeiro, RJ, Brazil. SBG.

GONÇALVES DF, DE PAULA RG, BARBOSA MR, TELES C, MAURITY CW \& MACAMBIRA JB. 2016. Lateritic terrains and the evolution of pseudokarstic features - case study in the iron ore mine N4E, Carajás Region - Pará, Brazil. In: 24th World Mining Congress. Rio de Janeiro, RJ, Brazil. Instituto Brasileiro de Mineração - IBRAM, 3: 242-251.

LOKE MH. 2001. RES1D ver. 1.0 for Windows 95/98/Me/2000/NT: 1-D Resistivity, IP \& SIP inversion and forward modeling. 12 pp.

MACHADO N, LINDENMAYER ZG \& KROGH TE. 1991. U-Pb Geochronology of Archean magmatism and basement reactivation in the Carajás area, Amazon Shield, Brazil. Precambrian Research, 49: 329-354.

MANNEY R, ROTH MJS \& NYQUIST JE. 2005. Exploring Directional Differences in Resistivity Results in Karst. In: SAGEEP. Oakland, California, USA, 1117-1124. EAGE.

MAURITY CW \& KOTSCHOUBEY B. 1995. Evolução recente da cobertura de alteração no Platô N1 - Serra dos Carajás - PA. Degradação, pseudocarstificação, espeleotemas. Boletim do Museu Paraense Emílio Goeldi. Série Ciências da Terra, 7: 331-362.

MEIRELES EM, HIRATA WK, AMARAL AF, MEDEIROS CA \& GATO VC. 1984. Geologia das folhas Carajás e Rio Verde, Província Mineral dos Carajás, estado do Pará. In: $33^{\circ}$ Congresso Brasileiro de Geologia. Anais. Rio de Janeiro, RJ, Brazil, SBG, 5: 2164-2174.
MORGAN FD, SHI D, VICHABIAN Y, SOGADE J \& RODI W. 1999. Resistivity in Cave Exploration. In: SAGEEP. Oakland, California, USA, 303-308. EAGE.

OLDENBURG DW \& JONES FHM. 2007. Inversion for Applied Geophysics; Learning resources about geophysical inversion. University of British Columbia, Canada, Geophysical Inversion Facility. Available on: <https://www.eoas.ubc.ca/ubcgif/iag/tutorials/invnconcepts/how.htm>. Access on: May 4, 2019.

PELLERIN L. 2002. Applications of Electrical and Electromagnetic Methods for Environmental and Geotechnical Investigations. University of Utah, Energy and Geoscience Institute. Salt Lake City, Utah 84112, USA. Surveys in Geophysics, 23: 101-132.

PILÓ LB \& AULER AS. 2009. Geoespeleologia das cavernas em rochas ferríferas da região de Carajás, PA. In: $30^{\circ}$ Congresso Brasileiro de Espeleologia. Montes Claros, MG, Brazil. Anais. SBE, 181-186.

PINHEIRO RVL \& MAURITY CW. 1988. As cavernas em rochas intempéricas da Serra dos Carajás (PA) - Brasil. In: $1^{\circ}$ Congresso de Espeleologia da América Latina e do Caribe. Belo Horizonte, MG, Brazil, p. 179-186. SEE (Sociedade Excursionista e Espeleológica).

PROSDOCIMI GAS, BARBOSA MR, BRANDI IV \& BRAGA MAS. 2018. Estudo de cavidade natural em formação ferrífera por meio da integração de métodos geofísicos rasos, Complexo Carajás, Brasil. In: $49^{\circ}$ Congresso Brasileiro de Geologia. Rio de Janeiro, RJ, Brazil. SBG.

ROSIÈRE CA \& CHEMALE JR F. 2001. Itabiritos e minérios de ferro de alto teor do Quadrilátero Ferrífero - uma visão geral e discussão. Revista Geonomos, 8(2): 27-43.

SANTOS JOS. 2003. Geotectônica dos Escudos das Guianas e Brasil-Central. In: BIZZI LA, SCHOBBENHAUS C, VIDOTTI RM \& GONÇALVES JH. (Eds.). Geologia, tectônica e recursos minerais do Brasil. Brasília, DF, Brazil: CPRM-Serviço Geológico do Brasil. texto, mapas e SIG. p. 169-226, il.

VASQUEZ ML \& ROSA-COSTA LT (Org.). 2008. Geologia e recursos minerais do Estado do Pará: texto explicativo do mapa geológico e de recursos minerais do Estado do Pará. Belém-PA, Brazil: CPRM. 328 pp. il. color. escala 1:1.000.000. Programa Geologia do Brasil (PGB). 